\title{
APARICIÓN E FLORECEMENTO DA PROSA MEDIEVAL GALEGA
}

\author{
Santiago López Martinez-Morás
}

Universidade de Santiago de Compostela

Normalmente, os investigadores, tanto no caso de medievalistas como no caso dos estudosos da literatura galega en xeral, consideran de xeito marxinal as obras en prosa vernácula da Galicia medieval, e isto, fundamentalmente, por dúas razóns: a escaseza de textos conservados, e o feito de tratarse, case na súa totalidade, de traducións a partir de obras ou textos creados fóra do noso territorio, o que resta orixinalidade á produción galega (Lorenzo 2000: 366-67; cf. porén, Gracia 1996: 12-13 para as versións castelás; vid. outras razóns en Gutiérrez García 2005: 37-40). Engádese a isto o feito de que a prosa galega forma parte do mesmo período histórico, o medieval, que asiste ao nacemento, apoxeo e desaparición da lírica galego-portuguesa, o xénero máis importante deste período, e un dos máis frutíferos da literatura galega ata o día de hoxe, o que acentúa inevitablemente o seu carácter secundario a ollos da crítica. Esta visión, máis froito da análise moderna que de consideracións propiamente medievais, afecta tamén a movementos líricos máis tardíos, como a denominada escola galego-castelá, que non imos tratar aquí, e que, en contraposición á anterior, é considerada claramente de decadencia pola investigación dos últimos tempos (Gómez Sánchez / Queixas Zas 2001: 63, Vilavedra 1999: 62, Polín 1997; cf. porén, Monteagudo 1999: 124 e Pena 2002: 298; vid. tamén, para unha acertada análise destas posturas, Gutiérrez García 2005: 32 e ss.); esta mesma crítica, non obstante, en liñas xerais, valora positivamente as escasas referencias prosísticas da literatura galega.

Pero é indispensable ter en conta que, polas súas características, a prosa é distinta da produción lírica, e está máis suxeita a un proceso de copia, difusión e tradución de manuscritos que require necesariamente a existencia de copistas e amanuenses, indispensábeis para o seu coñecemento e difusión. Este proceso podería denominarse fase 1, e é o que impide que, nun primeiro momento, poidan existir elementos de orixinalidade literaria (fase 2), que, nunha evolución lóxica, só podería xurdir despois de que este primeiro paso acadase unha certa complexidade. 
Esta segunda posibilidade, no caso galego, vese limitada polo importante desenvolvemento do sistema literario en castelán, moitísimo máis efectivo, o que trae consigo a consolidación da literatura castelá como sistema de referencia cultural no territorio galego; este sería o principal factor da inexistencia dunha literatura galega en prosa con xéneros propios desenvolvidos. Pero este fenómeno limítase ao ámbito da prosa, porque o xénero lírico constitúe unha cuestión distinta: a escola galego-castelá de finais da Idade Media proba que a pervivencia do galego como lingua de creación literaria mantiña o seu vigor en ámbitos moi definidos, ao tempo que conservaba vínculos evidentísimos coa antiga produción lírica da que esta escola sería, en realidade, epígono.

De todas maneiras, compre interpretar este primeiro proceso de traducións e adaptacións como parte dun fenómeno xeral de difusión e de continuidade común ao espazo europeo, non só hispánico. De feito, aínda que mantén a súa orixinalidade nalgúns puntos, a propia lírica galego-portuguesa é, en gran medida, debedora á súa vez dun proceso de produción occitano que foi quen de influír na xeración doutros movementos líricos. Á súa vez, a lírica galego-portuguesa difundiuse no territorio peninsular como escola literaria, propagando o uso da lingua; isto proba que os grupos culturais pechados son impensables na época medieval e, polo tanto, non é correcto supoñer que a produción prosística galega, polo feito de traducir directamente as obras procedentes do exterior, constitúe un proceso literario menor, senón que é, en realidade, parte dun fenómeno global no que, simplemente, a iniciativa partía agora doutros centros, hispánicos e europeos.

Por outra banda, tamén é necesario ter en conta, pola súa importancia nun sistema que conserva de xeito fragmentario gran parte da súa produción, que os textos conservados son só unha parte do que realmente existiu; así, de moitas obras temos algunha referencia puntual: por exemplo, as homilías en galego das que se teñen noticia en 1229 (Monteagudo 1985: 117) fan que poidamos supoñer unha produción de exempla ad usum praedican$d i$, de difusión oral, sen dúbida, pero que poderían ter existido por escrito nalgún momento. Polo mesmo motivo é preciso concederlles un certo papel na literatura galega deste período a aquelas obras que se mencionan, aínda que sexa de xeito indirecto, nos textos en prosa conservados; foron lidas por autores galegos e cítanse a propósito dun lector potencial galego, que probablemente os coñecía; isto implica que o proceso de difusión de obras noutras linguas, ou en versións galegas, foi maior do que nos deixan percibir os textos que hoxe lemos. Como se verá, parte do que segue se basea nesta premisa.

Como consecuencia, o presente traballo, que integra os achados de investigadores anteriores, e en particular, de Lorenzo (ed. 1975-77, ed. 1985, 
1993abc, 2000 e 2002), pretende ofrecer unha visión xeral da literatura galega en prosa destes séculos atendendo a una tripla orixe da produción (suxerida xa por outros investigadores, como Pena 2002: 296 e ss.):

a) unha dimensión europea, ou, máis propiamente, románica, onde xorden moitas das correntes e obras que teñen correspondente na literatura galega desta etapa, e que constitúen, segundo Vilavedra (1999: 67), o "rico substrato temático" da prosa medieval galega.

b) unha dimensión hispánica, produtora de obras derivadas dos discursos historiográfico e xurídico, e que constitúe, ao mesmo tempo, a principal rede de circulación de manuscritos na que se integra a produción galega.

c) unha dimensión propiamente galega, na que o número de obras é moi reducido, e cunha difusión claramente minoritaria, pero algunhas delas con base en textos, probablemente tamén moi vinculados a Galicia, de proxección universal ${ }^{1}$.

\section{A DIMENSIÓN EUROPEA}

A materia troiana, igual que a materia artúrica, que tamén deixou testemuños na literatura galega, ten a súa orixe en Francia. Concretamente, o Roman de Troie, a obra fundamental deste xénero e, con moito, a de maior éxito en Europa, foi escrita cara a metade do século XII, entre 1155-60, por Benoît-de-Sainte-Maure, por orde de Henrique II, rei de Inglaterra. Herdeiro de Dares e Dictis, autores de versións supostamente fidedignas dos feitos, pero escritas xa nos séculos IV e vi da nosa era, o Roman de Troie, de 30.000 versos, inaugura unha tradición que afecta a case toda a Romania, onde se combina con outros elementos e chega a condicionar parte da produción castelá nesta materia e, naturalmente, a produción galega. Ao longo deste século XII, e xa entrado o século XIII, será considerado como un texto que reproduce fielmente a historia troiana, pero sufrirá grandes transformacións, cheas de modificacións ideolóxicas e formais, como a redacción de varias versións en prosa.

1. A adscrición a unha destas categorías non implica a imposibilidade de pertencer a calquera das outras, porque, por exemplo, a materia troiana galega é de orixe europea, pero as obras conservadas nesta lingua dependen da producción castelá; porén, a clasificación establecida atende, fundamentalmente, ao lugar do xurdimento da materia dun texto. A orde que seguirán os relatos dos que falaremos, e o seu proceso de transmisión, obedecen a esta lóxica. Por tal motivo, serán frecuentes neste traballo as referencias a procesos de creación e difusión de obras estrañas ao sistema galego, pero estreitamente relacionadas con el. 
Esta segunda vía de produción da materia troiana non debe entenderse como substitutiva da primeira, en verso, senón como complemento da mesma, de tal xeito que, nun momento dado, a obra de Sainte-Maure coñeceu dúas vías de propagación: a da fórmula orixinaria e a propiciada polas prosificacións. Pero é preciso falar de prosificacións en plural, porque en realidade existen cinco versións distintas deste proceso, tal e como indican os investigadores. Estas versións son coñecidas dende hai tempo, pero foron analizadas en profundidade nos últimos anos sobre todo por Jung (1996). Estas prosificacións, designadas numericamente de 1 a 5 , foron case todas elas redactadas no século XIII, na centuria seguinte ao traballo de Benoît, e teñen orixes distintas: con excepción de Prose 5, todas elas son de produción non francesa: Prose 1 provén de Morea, Prose 2 (chamada impropiamente "versión meridional") da Italia setentrional; Prose 3 foi redactada en Italia central e Prose 4 (que inclúe a historia de Troia nun relato sobre o Graal (versión Bodmer), no reino anxevino de Nápoles. Prose 5 é fundamentalmente coñecida pola súa inserción na segunda redacción da Histoire ancienne jusqu'à César, onde substitúe á historia de Dares da primeira redacción desta obra (Jung 1996: 440-563).

Pero a "versión meridional" coñeceu unha reformulación latina, a Historia destructionis Troiae, efectuada por Guido delle Colonne cara a 1287, que viría complicar en gran medida a difusión da materia troiana. Este relato constituíu pronto unha terceira vía de difusión da lenda troiana entre as xeradas a partir da obra versificada de Benoit, ata o punto de que, en certo momento, chega a substituír ao propio autor francés como fonte principal da historia, sobre todo en datas tardías (Lorenzo 2002: 110). Na Península Ibérica, sen ter en conta as pasaxes de Guido integradas na Polimétrica tex to castelán do que falaremos de seguido- as primeiras traducións están documentadas fundamentalmente a partir de 1375, data na que Jaume Conesa traduce esta obra ao catalán, quizais a partir dun texto francés intermedio; pola súa banda, as traducións aragonesa (Juan Fernández de Heredia, finais do XIV), e castelá (Pedro de Chinchilla, Ystoria troyana, 1443) son aínda mais tardías.

Non temos probas dunha tradución galega desta última versión sobre Troia, pero si podemos establecer hipóteses sobre redaccións en galego do Roman de Troie anteriores aos textos conservados e, en particular, en relación a un dos primeiros textos da produción troiana en castelán: a Historia troyana polimétrica. Esta obra consérvase en dous manuscritos fragmentarios: o códice M (ms. 10146 da BNM) contén, no seu núcleo orixinario, unha tradución dos versos 5703 a 15567 do Roman de Troie. O outro testemuño, de finais do XIV, é o manuscrito M' ou E (L-ji-16 de El Escorial), que traduce os versos 13822 a 15567 de Benoît. Ambos os dous están completados, tar- 
diamente e en diferentes niveis, por fragmentos procedentes da versión do Roman de Troie de Afonso XI, aínda que, máis puntualmente, o manuscrito E contén tamén elementos tomados de Guido delle Colonne (García Solalinde 1916: 124-6), o que implica a unión, certamente accidental, das dúas versións da materia troiana en Castela. A datación tradicional da Polimétrica, situada cara a 1270, segundo Menéndez Pidal, non foi sempre aceptada de xeito unánime (p. ex. García Solalinde 1916: 127, recentemente Casas Rigall 1999: 215-6), de tal xeito que podería chegar a situarse a súa orixe xa no século xIv, quizais en datas próximas á da versión da Historia Troyana de Afonso XI, o outro gran testemuño da materia troiana no reino castelán (fundamental, pero non único na difusión da materia: ademais dos manuscritos que completan esta tradición, sábese que houbo en Castela un manuscrito de Prose 5, de ca. 1345, ofrecido por Henrique II de Castela a Charles V de Francia. Cfr. Jung 1996: 505). Con todo, a modificación da data non é a única novidade de importancia: Juan Casas (1999: 235) atopa problemas de tradución na Polimétrica, na que Ménendez Pidal xa vira leonesismos (Menéndez Pidal ed. 1934: xxii, e n.1), que poderían supoñer a existencia dunha fonte galega ou portuguesa. Isto implica que a Polimétrica compartiría a fonte do testemuño fundamental hoxe conservado da versión da Historia Troyana de Afonso XI, o H. j. 6 de El Escorial, acabado de copiar en 31 de decembro de 1350 (García Solalinde 1916: 129), no que Ramón Lorenzo (ed. 1985: 191-202) xa atopara problemas semellantes que evidenciaban tamén unha fonte galega ou portuguesa, froito da tradución, no Occidente peninsular, dun manuscrito francés quizais traído por Afonso III o Boloñés (Lorenzo 2000: 401).

Á vista destas hipóteses, dadas as circunstancias e as análises lingüísticas da Polimétrica $€$ - os leonesismos tamén atopados por Menéndez Pidal- se ambos textos, a Polimétrica e a Historia Troyana, tiveron unha orixe común, como propón Juan Casas, o máis plausible sería quizais supoñer que esta actividade de tradución no Occidente peninsular, da que fala Lorenzo, podería ser, en realidade, a que se desenvolveu na zona de León no século XIV e que, ademais de afectar ao proceso de difusión dalgúns relatos artúricos, como veremos despois, tamén propiciou a creación e circulación de textos xurídicos en galego-leonés (Mariño 1998: 157-76); nestas condicións, non é imposible supoñer que foi nesta rexión leonesa onde se redactou este modelo troiano con leonesismos común a ambos textos casteláns, como suxire Casas: "la combinación de elementos leoneses y galaico-portugueses que se advierte en la Polimétrica incluso podría figurar ya en el modelo ibérico perdido" (Casas 1999: 236). Esta hipótese vincula de xeito inequívoco a produción en prosa galega coas actividades culturais do reino de Castela e León, algo que se reproducirá tamén noutros xéneros. 
De feito, a implicación da creación galega nun fenómeno máis xeral se percibe máis claramente nos manuscritos conservados. Á parte da hipótese que acabamos de propoñer acerca da fonte galega sobre a materia de Troia e os seus posibles alcances, coñecemos unha tradución galega da Historia Troyana de Afonso XI, efectuada a partir dun manuscrito diferente do referido arriba, e hoxe perdido (Lorenzo ed. 1985: 169 e ss.): trátase da Cronica Troiana, traducida do castelán por Ferran Martíns e outros copistas por orde de Fernán Pérez de Andrade e rematada en 1373, resultado logo dun labor de mecenado que proba, dende a nosa perspectiva, a diversificación dos ámbitos culturais da produción galega, a existencia de pequenos centros de produción $m$ oi asimilables, na súa función, a outros centros señoriais, non rexios, de Occidente- e a súa progresiva integración en varios niveis do sistema literario hispánico.

A materia troiana en galego ten aínda outro testemuño máis, esta vez de carácter menor: trátase do ms. M.558 da Biblioteca Menéndez y Pelayo de Santander, do século XIV, que presenta dous aspectos fundamentais: a) combina o uso do galego co castelán, pero de xeito independente, de tal forma que o texto en galego serve para completar as lagoas que presenta o texto en castelán, lingua inicialmente utilizada para a redacción desta copia (Lorenzo 2000: 402). Isto, en principio, limita a importancia da achega galega na redacción, porque foi simplemente a lingua dun amanuense puntual a que determinou en último termo a integración deste texto no sistema literario galego, e b) en canto ao contido, o manuscrito introduce elementos sobre materia antiga tomados da General Estoria (Parker ed. 1975: ix) sobre todo no principio do texto, que combina cos datos básicos da materia troiana tal e como a coñecemos polo testemuño da produción de Afonso XI, a cuxa tradición manuscrita pertence. En consecuencia, o manuscrito de Santander completa unha traxectoria en tres niveis da produción galega sobre a materia de Troia: en primeiro lugar, a posible versión, quizais vinculada a León, directamente dependente das achegas de Afonso III á súa vez debedor da produción francesa- e orixe de textos casteláns capitais como a Polimétrica e a Historia Troyana de Afonso XI; en segundo lugar, unha tradución galega deste último texto, que constitúe, xunto coas traducións de crónicas, a proba máis importante da existencia dunha actividade cultural nas cortes señoriais galegas; e, en terceiro lugar, un testemuño puntual da tradición manuscrita da Historia de Afonso XI, que demostra a interrelación dos usos lingüísticos, aínda que accidentais, do galego e o castelán (o que demostra, por outro lado, o amplo grao de intelixibilidade da escrita das distintas variantes iberorromances por parte dun certo público). Os pasos referidos consolidan a idea dunha circulación indistinta de manuscritos en varios romances peninsulares como partes dunha mesma tradición sobre a materia, ademais dos 
manuscritos sobre Troia que, sen dúbida, circulaban en francés nun primeirísimo momento, chegados tamén con certeza por vías distintas á portuguesa, e dos que a penas temos noticia.

Un proceso case idéntico, que ten como gran protagonista a Portugal, é o representado polas materias artúrica e tristaniana, de pouco posterior, no escenario europeo, á materia antiga. A literatura artúrica en lingua vulgar aparece neste contexto global no século xII, e ten o seu principal expoñente en Chrétien de Troyes, que foi autor, na segunda metade dese século, das obras máis salientables do xénero. Só despois de 1210 empeza a fraguarse a elaboración de ciclos en prosa, os máis importantes dos cales, coñecidos como Vulgata e Post-Vulgata, van ter un gran éxito como transmisores da literatura artúrica en Europa.

Estes ciclos tiveron unha complicada xénese, e unha máis complicada difusión: o da Vulgata, conformado entre 1215 e 1235 (Frappier 1978: 538), comezou a consolidarse a partir da principal das súas obras: o Lancelot du Lac, á que se engadiron a Queste du Saint Graal e a Mort Artu. Con posterioridade a estas obras foron creadas a Estoire du Graal e o Merlin, que pechan o conxunto; a Post-Vulgata, que é completada cara 1240, elabora unha visión nova da historia artúrica a partir do esquema da Vulgata, pero non presenta outra versión do Lancelot du Lac, a obra central do ciclo. Neste segundo grupo, a conservación de testemuños franceses é tan escasa que o contido das traducións ibéricas € - astelá e portuguesa- é indispensable para a reconstrución do conxunto. Por outra banda, a estes ciclos engádese unha obra dunha fortuna inmensa na literatura medieval, o Tristan en prose, que, na súa orixe cara a 1240 nas versións máis divulgadas, foi concibida como unha continuación necesaria dos outros ciclos, que non falaban das aventuras do personaxe de Tristán. De todas formas, as súas aventuras, aínda que dun xeito totalmente diferente, foran xa tratadas por Béroul e Thomas d'Angleterre no século anterior en sendas obras versificadas.

Os únicos testemuños conservados na Península Ibérica desta produción artúrica, son, precisamente, as traducións de diversos textos pertencentes aos ciclos referidos, que vinculan, a través de certas referencias puntuais, a Portugal e a Castela. Galicia, que non ten traducións conservadas de ningún dos dous ciclos artúricos, e só dispón dun fragmento dunha tradución do Tristan en prose, parece claramente excluída deste proceso. Pero, como xa dixemos na introdución deste traballo, neste campo ten un peso importante a opción da literatura perdida: parece claro que Galicia tivo, alomenos, coñecemento indirecto destes ciclos e, en xeral, da produción artúrica de Occidente, como proban algunhas referencias da lírica galego-portuguesa (Alvar 1993, Sharrer 1988, Gutiérrez García / Lorenzo Gradín 2001: 56-109). É fácil imaxinar, pois, que ambas materias, artúrica e tristaniana, tiveron plena circulación no Occi- 
dente peninsular, incluíndo Galicia e, posiblemente, compartiran nalgúns casos (sobre todo na Vulgata, a Post-Vulgata e o Tristan en prose), algún elo común que explique a chegada dos textos a estes territorios ibéricos.

Á marxe das vías secundarias de penetración, normalmente considérase fundamental para o coñecemento de certos textos artúricos o papel desenvolvido por Afonso III o Boloñés, irmán de Sancho II, ao que sucedeu no trono de Portugal en 1248. Ata pouco antes, o Boloñés permaneceu en Francia, casado con Matilde de Boulogne, e mantivo un contacto moi estreito cos ámbitos literarios e de cultura do país de acollida. As datas da súa estadía en Francia permiten supoñer que tamén coñecería os ciclos en prosa dos que antes falábamos, a Vulgata e a Post-Vulgata, aínda que algúns investigadores sosteñen que tamén é posible que coñecese unha primeira versión do Tristan en prose (Gutiérrez García / Lorenzo Gradín 2001: 43), datada cara 1235, anterior ás que hoxe coñecemos. Non obstante, as referencias que conservamos hoxe só demostran vínculos deste rei coa Post-Vulgata, e isto a través dun personaxe histórico mencionado no José de Arimateia portugués (Carter ed. 1967: 379) e na Demanda del Santo Grial castelá: João Vivas (ou Juan Vivas), relacionado con Joan Sánchez, mestre escola da diocese de Astorga e responsable dunha certa labor de tradución de textos artúricos cara a 1314, personaxe mencionado a súa vez no colofón do texto portugués. A nacionalidade de Vivas foi obxecto de controversia ata que Ivo Castro (1983) probou a existencia dun João Vivas, crego da orde de Santiago, que viviu en Lisboa nos tempos do Boloñés; en consecuencia, a tradución inicial dos textos da Post-Vulgata sería feita por este crego, case con seguridade, do francés ao portugués. Con todo, as versións portuguesas conservadas non provirían deste primeiro proceso, porque este colofón do José de Arimatea, onde se menciona a Joan Sánchez, obrigan a pensar nunha nova actividade de tradución e copia desenvolvida na localidade de Astorga cara a principios do século XIV, como sostén o propio Castro (1983: 98), que constituiría a orixe dos actuais testemuños manuscritos.

Neste sentido, é salientable un caso que aínda non está esclarecido totalmente a falta dunha edición crítica do texto. Trátase do problema representado polo manuscrito 9611 da Biblioteca Nacional de Madrid, recentemente publicado, que reproduce un texto en castelán do Lancelot du Lac da Vulgata, o outro gran ciclo artúrico. Este manuscrito, datado no século xvi, que é copia, segundo se indica explicitamente nel, doutro de 1414, presenta arcaísmos que poderían retrotraelo ás datas que manexamos, de 1314, na que se situaba a actividade tradutora de Astorga (Viña ed. 1993: 38-47). De feito, H. Sharrer (1994) percibe trazos lingüísticos que suxiren unha orixe noroccidental da fonte, sen que sexa posible determinar, polo de agora, a procedencia exacta, leonesa, galega ou portuguesa; isto suxire a Castro (1998: 
139) a posibilidade de que o Boloñés fora tamén o responsable da chegada de, alomenos, unha parte do ciclo da Vulgata á Península, onde seguiría, loxicamente, o mesmo proceso que os textos da Post-Vulgata e, como vimos polas propostas xa citadas de Lorenzo e Casas, tamén do Roman de Troie.

Por fin, o Tristan en prose galego constitúe un caso inverso aos que acabamos de tratar: se o ciclo da Post-Vulgata presentaba varios textos portugueses e ningún galego, o Tristan presenta xustamente o problema contrario, porque o fragmento galego non ten correlatos portugueses conservados. Non obstante, parece ser que houbo un manuscrito do Tristan na biblioteca de Don Duarte (Lorenzo 2002: 111). O fragmento pertence á chamada versión VII (segundo a terminoloxía que utiliza, entre outros, Baumgartner 1975: 61-62), a mais difundida en Europa, e formada cara a 1240, pero á que non pertencen os testemuños casteláns, o que suxire unha orixe e unha difusión independentes do noso fragmento con respecto a este grupo (Cuesta Torre 1994: 240). De todos os xeitos, a complexidade das versións é tan grande, igual que o número de manuscritos de VII, que resulta moi difícil establecer a fonte precisa da cal procede o texto galego, aínda que investigacións recentes parecen achegar dunha certa maneira esta última versión ao ms. 2542 de Viena (López Martínez-Morás 1999: 852, López Martínez-Morás / Pérez Barcala 2001: 123, Lorenzo Gradín / Díaz 2004: 395), sobre o que Philippe Ménard estableceu a partir de 1987 a súa edición do roman de Tristan en prose, aínda que non sexa posible aceitalo como manuscrito fonte. De feito, algúns investigadores perciben unha gran semellanza con outros testemuños (p. ex. Michon 1991: 266, Soriano 1998: 674).

Esta particularidade do texto galego evidencia a multiplicidade das vías de difusión das materias artúrica e tristaniana pola Península. Pero iso é lícito pensar que, con alta probabilidade, tamén un manuscrito do Tristan en prose formaría parte do conxunto de obras traídas polo Boloñés a Península. Cronoloxicamente é posible: aínda que a creación do Tristan en prose primitivo se sitúa arredor dos anos 1225-35, hai ata catro versións posteriores a esta data que chegan ata mediados do século xIV. A data a quo da versión VII, fonte do texto galego é, como xa dixemos, 1240 (Baumgartner 1975: 62), polo tanto algúns anos anterior á volta do Boloñés a Lisboa. Por outra banda, o texto tristaniano galego, que data das últimas décadas do século XIV (Pensado ed. 1962: 12, Rossi 1993: 414 fala, concretamente, do "terceiro quarto do século XIV") é claramente copia doutro anterior (Michon 1991: 268, Castro 1998: 148, López Martínez-Morás 1999: 850; cf. porén, Pensado ed. 1962: 12), o que nos permite aproximarnos cronoloxicamente a todo o proceso de tradución e difusión dos tempos de Afonso III e dos anos seguintes en Astorga. É moi posible pois que, nestas condicións, a achega do Boloñés ás literaturas peninsulares sexa maior do que pensamos, aínda que non poidamos es- 
quecer o papel esencial e obvio neste proceso doutras vías de penetración como o Camiño de Santiago, segundo propón, entre outros, Lorenzo (2002: 107, tamén Gutiérrez García 1998).

Neste proceso de produción a partir de textos foráneos existe un texto que non ten as repercusións dos anteriores, pero que tamén forma parte dunha tradición europea, aínda que menor que as outras, e de carácter esencialmente utilitario, e incluso claramente técnico: o chamado Libro de albeitaria. Este é un tratado práctico de veterinaria datado, como moi tarde, cara a 1420; comparte cos que nós chamamos textos da "dimensión galega" (vid. infra) a data tardía e o alcance reducido, pero, paradoxalmente, este texto marxinal é moi próximo no tempo do que quizais sexa o documento historiográfico galego máis importante, a Crónica de 1404. Como moitos outros textos romances, o tratado aparece integrado nun manuscrito, hoxe desaparecido (Lorenzo 1993c: 635), que contiña outros elementos non relacionados co texto en cuestión, e que incluía documentos do notario de Baiona Álvaro Eanes da Seira, autor de varias actas notariais presentes no manuscrito e datadas entre 1409 e 1420 (Lorenzo 1993c: 635 e 2000: 427). A súa fonte exacta sería un tratado de veterinaria, o De medicina equorum, escrito en Nápoles por Giordano Rufo, mariscal do emperador Federico II, morto en 1250. Esta obra inicial estaría escrita arredor desa data ou, en todo caso, antes de 1256, dado que nese momento a familia Rufus, caída en desgraza co novo soberano Manfredo, perde a súas pertenzas e a súa influencia.

O texto galego forma parte dunha complexa rede europea de traducións da obra, porque o De medicina equorum, que recibe influencia incluso de obras clásicas como a Mulomedicina Chironis, coñece versións nas linguas máis importantes da Romania, ademais de ser recollida en múltiples manuscritos en latín, dos que se conservan aínda hoxe uns 26. Sen embargo, parece que non todas as áreas da Romania coñeceron por igual a obra de Rufus: Prévot (1991: 7) establece una lista das versións romances existentes, pero non fai referencia a ningún caso ibérico, con excepción dos textos cataláns, repartidos entre os séculos XIV e o XV. No Occidente peninsular, á parte da versión galega, existe unha tradución en portugués, a versión de Mestre Giraldo, elaborada por encargo de D. Dinis cara a 1318, e que constitúe unha das primeiras traducións da obra de Rufus en Europa. Esta versión, que Pena (2002: 339) parece dalgún xeito equiparar á galega, ten, porén, fontes máis complexas, porque presenta tamén unha marcada influencia da Mulomedicina de Fr. Theodorico Borgognoni (Vasconcelos 1910: 156 e ss., Pensado ed. 2004: 18), que a separa claramente da versión galega (Lorenzo 1993b: 405). Por outra banda, en castelán é coñecido, sobre todo, un Libro de los caballos, tradución da obra de Theodorico Borgognoni, que, segundo os investigadores, dataría dos tempos de Afonso XI, e estaba dirixido á nobreza (Rodríguez Velasco 
1996: 391-92); pola contra, o texto galego parece estar concibido claramente para un uso práctico de clases baixas (Pensado ed. 2004: 18) ${ }^{2}$.

De todos os xeitos, a versión de Mestre Giraldo engade unha valiosa referencia á circulación de ambas obras, a de Rufus e a de Borgognoni, en Portugal (Lorenzo 1993b: 405), o que permite imaxinar o contexto cultural ibérico e, polo tanto, galego - no que o notario baionés tería accedido á obra de Rufus para elaborar a súa versión. Aínda así, non se pode definir con exactitude a natureza, as características ou a lingua da fonte da versión galega: é posible aceptar, con Ramón Lorenzo (2000: 428) e Pensado (ed. 2004: 18) que se trata dunha copia dun texto algo máis antigo, aspecto ratificado, en traballos de investigación aínda inéditos, por Pérez Barcala; pero a súa fonte exacta, un orixinal latino, próximo á obra de Rufus, ou unha tradución romance, non está aínda clara. Non obstante, segundo afirma o investigador Pérez Barcala nun traballo en prensa ${ }^{3}$, moi probablemente a fonte do texto galego sería unha versión latina e non unha fonte vulgar, a xulgar polos latinismos léxicos e sintácticos que presenta o tratado. Esta fonte latina, de difícil determinación, sería quizais próxima á que lemos no manuscrito da Biblioteca Marziana de Venezia, Lat. VII. 24 (3677), do século XIII, publicado en 1818 por Girolamo Molin.

\section{A DIMENSIÓN HISPÁNICA}

A dimensión europea é fundamental na materia de ficción (e, puntualmente, no tratado de veterinaria que precede a este apartado), pero esta ten, esencialmente, un sistema de transmisión netamente hispánico, como acabamos de ver. Tamén ten unha dimensión esencialmente hispánica, esta vez na súa produción, a maior parte do discurso historiográfico galego deste período, na medida en que depende, nos seus textos máis importantes, da produción afonsít ${ }^{4}$. As obras desta parte son tres: a) unha tradución conxunta, de principios do século xIV, da Crónica General (coñecida sobre todo como Estoria de España) e da Crónica de Castilla (un manuscrito menor, A', inclúe

2. "Estamos ante una copia de un texto muy curioso, de naturaleza pragmática, carente de preocupación literaria, y probablemente para uso, no de un distinguido caballero amante de los caballos, sino más bien para el de un albéitar o de un caballerizo que los cuida".

3. O traballo será publicado na Revue critique de Philologie Romane. Este investigador, que continúa o seu labor sobre o Libro de Albeitaria, prepara unha nova edición do texto e un estudo complementario como base da súa tese de doutoramento.

4. A Crónica de Santa María de Iria é tamén un texto historiográfico pero, como ten unha dimensión exclusivamente galega, trataremos del na última parte deste traballo. 
só a tradución do primeiro destes textos; vid. infra a descrición correspondente); b) a chamada Crónica de 1404, que inclúe a anterior entre as súas fontes, e c) unha tradución parcial do século XIV da General Estoria afonsí, que só chega a cubrir unha parte pequena da produción desta crónica universal do Rei Sabio, o cal deixou sen concluír este gran proxecto.

O primeiro texto, tradución conxunta da Crónica General e da Crónica de Castilla (orixinariamente independentes entre si en castelán), consérvase só nun manuscrito: o 8817 da BNM (elaborado entre 1295 e 1312, sendo rei de Castela Fernando IV; vid. Catalán 1962: 354, Lorenzo ed. 1975: xlvi). Este manuscrito, denominado A, entre outros, por Diego Catalán (1962), traduce, na súa primeira parte (A1) a chamada versión amplificada de 1289 da Estoria de España de Afonso X, pero non na súa totalidade: en concreto, só presenta unha versión galega da parte comprendida entre os reinados de Ramiro I (842-850) e Vermudo III (1028-1037), reis de León, que constituía, no orixinal castelán, o texto inicial de $E 2 c$, documento historiográfico independente que foi despois integrado no manuscrito rexio E2, esencial na configuración da Estoria de España (Lorenzo ed. 1975: xxxviii, Catalán 1962: 50-52). Non obstante, esta versión castelá E2c continúa coa narración de reinados posteriores ata ben entrado o de Afonso VI (Fernández Ordóñez 2000: 243); a tradución galega é, polo tanto, parcial. Pola súa banda, a segunda parte de A (A2) traduce, como xa sabemos, a Crónica de Castilla, texto creado entre 1290 e 1300 (Armistead 2000: 160) a partir de elementos tomados da Estoria de España (Fernández Ordóñez 2000: 223). Esta crónica, na súa versión orixinal, cubre os reinados de Fernando I a Afonso IX (Bautista Crespo 2002: 285, Catalán 1962: 345), reis posteriores aos citados en A1. Porén, á versión galega deste texto que lemos en A2 se lle engadiron certos elementos independentes, e, a maiores, a Crónica Particular de San Fernando.

A presenza de textos tan dispares nun só manuscrito $1-$ émbrese que estamos a falar en todo momento do manuscrito A- fai pensar que o proceso de elaboración do mesmo, desentrañado, entre outros, polo seu editor, R. Lorenzo (ed. 1975-77) e por Diego Catalán (1962, 1992, 1997), foi dunha extraordinaria complexidade. En efecto, a primeira complicación empeza, de feito, na orde de tradución dos documentos: foi A2, e non A1, a parte redactada en primeiro lugar. Isto se sabe porque A2 presenta unha introdución, tomada do Liber Regum navarro, que reproduce un esquema xenealóxico dos reis anteriores (Lorenzo ed. 1975-77: xxxviii, xli-xlii), algo inútil nunha hipotética configuración unitaria do manuscrito A, porque repite parcialmente o que se mostra en A1 (Catalán 1962: 315-16). Antes incluso da unión con esta parte, e co fin de actualizar o discurso histórico, engadiuse a A2 unha sucinta historia dos últimos anos de Fernando III e dos reinados de Afonso X e Sancho IV, para rematar no período do reinado de Fernando IV, ao que 
chama rei (Catalán 1962: 352, Lorenzo ed. 1975-77, xlii, e 2000: 368), o que permite datar a tradución, que sería composta, como moi tarde, en 1312, ano en que remata o reinado de Fernando IV (Lorenzo ed. 1975-77: xlvi). Esta parte sufriu serias modificacións que veremos nun momento.

Neste estado de cousas, foi engadida a continuación unha tradución da versión E2c, que xa coñecemos como A1, e que serviu para cubrir o período anterior a Fernando I, no que comezaba a tradución da Crónica de Castilla. Este documento castelán, aínda que chega máis lonxe no tempo que a tradución galega, só contiña os reinados a partir de Ramiro I de León (Catalán 1962: 53), de tal xeito que a parte anterior a esta, cos primeiros reis astur-leoneses, incorporada despois, non formaba parte de texto orixinal traducido ao galego (Catalán 1962: 52, Lorenzo ed. 1975-77: xliv); polo tanto, tampouco existe na versión editada por Lorenzo, o que impide falar dun problema de transmisión manuscrita a partir dun hipotético orixinal completo (fronte a opinión de Monteagudo (1994a: 34 e ss.) e Vilavedra (1999: 78)).

Cando este proceso estaba concluído, unha man distinta ás anteriores eliminou as referencias que contiña A2 sobre os reinados posteriores a Afonso IX, para establecer modificacións de gran calado: foi introducida unha interpolación da Crónica de San Fernando (A2cont, segundo a terminoloxía de Catalán) relativa á vida de Fernando III, para o cal foi eliminada unha parte do capítulo actualizador do que falamos, entre os folios 229 e 230, que seguía a A2. A eliminación, non obstante, non foi total, porque o capítulo foi introducido de novo despois desta interpolación, de tal xeito que a conclusión do texto, situada no reinado de Fernando IV, é a mesma (Lorenzo ed. 1975-77: xlii). Naturalmente, este longo proceso fai que o manuscrito A galego sexa o primeiro testemuño conxunto destas dúas obras, que, loxicamente, circularían por separado f- undamentalmente en castelán — antes da integración nun único manuscrito.

A pesar da complexidade na súa composición, é posible trazar unha certa influencia desta versión galega, que estaría presente, con variantes, na Crónica de 1344 do conde de Barcelos, texto historiográfico portugués, e na chamada Crónica de 1404 (Lorenzo 2000: 372). A crónica portuguesa, aínda que debedora da versión galega, posiblemente coñecería outros manuscritos distintos de A1, porque inclúe textos omitidos por este e que se atopan no orixinal da Estoria de España (Catalán 1992: 189-192 reproduce pasaxes do texto do conde de Barcelos omitidos en A1 e A'). Por esta razón, Diego Catalán considera que houbo dúas versións manuscritas, consultadas polo conde de Barcelos, próximas a A1 e A2, que o investigador denomina * $\alpha 1$ e * $\alpha 2$ (Catalán 1992: 189-91), hoxe perdidas. Estas versións terían circulado por separado pero, sempre segundo este investigador, tampouco elas constituirían a fonte da Crónica de 1404, o outro gran texto influído pola versión galega 
editada por Lorenzo: esta Crónica de 1404 reproduce claramente A2 para a parte relativa a Crónica de Castela, aínda que, para o texto da Crónica Xeral, utiliza unha versión de A1 distinta da que coñecemos, denominada *Ax, máis próxima do contido de A', que derivaría dela (Catalán 1992: 193-95, 1997: 239-40). É posible que, en todo este proceso, existira unha circulación por separado das traducións galegas da Crónica General e da Crónica de Castilla, cousa que non é en absoluto descartable pero é máis fácil pensar que ambos os dous textos puideron estar unidos en data relativamente temperá (Lorenzo 2000: 367 fala de "época indeterminada" na que foron unidos os dous textos), ou que, alomenos, como suxire Catalán (1992: 195-6), se difundise a "noción de que esas dos traducciones independientes constituían dos partes de una misma obra". Isto fai pensar que, dalgún xeito, existiu unha tradición manuscrita conxunta dos dous documentos en galego, dun certo grao de consolidación, que, como mínimo, divulgou a idea de que ambos relatos formaban parte dun único texto historiográfico, algo que foi esencial na xénese da constitución de varias crónicas distintas, pertencentes a reinos distintos, e vinculadas á Estoria de España afonsí.

$\mathrm{Na}$ mesma liña explícase a influencia do testemuño galego menor da Crónica Xeral: como xa dixemos, o manuscrito A' (2497 de Salamanca, antes 910 da Biblioteca do Palacio Real, século xv), texto menor desta tradición manuscrita galega, só contén a tradución da Estoria de España da versión amplificada traducida en A1. En principio pensouse que este testemuño non tivera influencia algunha posterior, pero novamente Catalán (1992: 188 e ss., tamén Fernández Ordóñez 2000: 240) determinou a dependencia do ms. castelán 643 de Madrid ( $A e$; finais do século xv) con respecto a esta versión, á que segue fielmente. Ao mesmo tempo, o investigador dá por seguro un vínculo de ambos os dous textos con Mondoñedo, deducido a partir dunhas referencias do texto de A' a esta localidade (texto en Catalán 1992: 188-89), que ambos reproducen, e que, en realidade, se desenvolven a partir dunha nota marxinal presente xa no ms. A1 (fol. 14b, Catalán 1992: 189). Isto implica, segundo Catalán (1992: 196), que todos estes manuscritos, incluíndo os que inflúen na crónica de 1404, tiñan algún tipo de relación con esta localidade galega, o que situaría, alomenos xeograficamente, a orixe desta incipiente tradición manuscrita en galego da que antes falábamos, e que, como vemos, reforza progresivamente o papel de determinados centros de poder na creación da prosa.

Pola súa banda, a Crónica de 1404 tamén participa, como xa quedou dito, nesta evolución dos feitos. Esta crónica, como xa sabemos, ten unha forte influencia da Crónica Xeral e da Crónica de Castela, que reproduce de xeito íntegro nunha das súas partes (Lorenzo 2000: 387) — quizais a partir dun manuscrito galego hoxe perdido no que se refire á Crónica Xeral (vid. supra)—, 
pero que non están incluídas na edición que fixo do texto Pérez Pascual (1990). Os testemuños desta crónica mostran unha maior complexidade que os textos historiográficos anteriores, non só no que se refire á composición, senón tamén á cuestión lingüística: o ms. S, da Biblioteca Menéndez y Pelayo de Santander (m-62), escrito, segundo Pérez Pascual, en galego-portugués (2002: 326, 1994: 249 n. 2), é de principios do século xv; os seus 162 folios só abranguen dende a historia de Fernán González ata a ocupación de Valencia polo Cid (Lorenzo 2000: 384). Pola súa banda, o manuscrito E (X-i-8 do Escorial), de mediados do século Xv, tamén é fragmentario: ten 331 folios, presenta notas marxinais de diversas mans e épocas, e interrómpese no reinado de Afonso VI e a historia do Cid. Contén unha tradución castelá, aínda que con moitos erros e galeguismos (Lorenzo 2000: 384). Finalmente, o principal testemuño, e o único completo, é o códice V (ms. Vindel, propiedade da Hispanic Society de Nova York), que data de finais do século xv e ten 363 folios, aínda que presenta unha versión castelá con galeguismos ata o folio $58 \mathrm{v}$, momento en que abandona esta lingua para utilizar unicamente o galego, que é a lingua da crónica orixinal. Moi probablemente, o que se pretendía neste manuscrito era unha tradución ao castelán, pero as dificultades coas que se atopou o copista, sen dúbida galego, fixéronlle renunciar a este proxecto para continuar na súa lingua (Pérez Pascual 1991a: 219). As filiacións entre todos os testemuños son moi simples, e xa foron establecidas polo seu maior coñecedor, Pérez Pascual (2002: 327), segundo o cal E e V derivarían de S. Ademais destes manuscritos, tense noticia de, alomenos, dous códices perdidos: o que figuraba na biblioteca imperial de San Petersburgo e o manuscrito do que dá noticia Maldonado y Pardo en 1677 (Pérez Pascual 2002: 325-6).

Poden establecerse no seu contido catro partes diferenciadas (Pérez Pascual 1994: 248-9, Lorenzo 2000: 384-89):

1) a parte relativa á Antigüidade ata o inicio do dominio godo na Península, na que se complementan varias fontes distintas, e que comparte contidos coa refundición da Crónica de 1344 (Fernández-Ordoñez 2000: 230-1); entre esas fontes estaría o Corpus Pelagianum, de Pelayo de Oviedo, cronista morto a mediados do século xII, que transcribe a Isidoro de Sevilla, quizais nun texto próximo ao conservado no ms. da BNM 1513 (Pérez Pascual 1994: 256). Pero tamén é aquí onde se introducen as referencias aos textos de ficción, dunha importancia extraordinaria para o coñecemento da súa difusión na Idade Media hispánica (e, polo tanto, tamén galega): o Libro de la Conquista de Troya, o Libro del Sancto Grayal, o livro del Valadro del Sabio Merlín entre outros (vid., a este respecto, Gutiérrez García / Lorenzo Gradín 2001: 53); 
2) dende a chegada dos godos, nos que segue un códice da versión crítica da Estoria de España (Fernández Ordóñez 2000: 260) ata o segundo ano do reinado de Afonso I, momento no que introduce unha xeografía universal, probablemente tomada das Etimoloxías de San Isidoro a través dunha xeografía medieval (Lorenzo 2000: 386);

3) os reinados de Ramiro I a Fernando III, parte na que reproduce de xeito fiel o que aparece na Crónica Xeral galega, nun texto hoxe non conservado, *Ax, que, como se indicou, Diego Catalán (1992: 193195) considera máis próximo a A' que a A1 (e que non reproduce a tese de Pérez Pascual, como xa dixemos); tamén reproduce fielmente a Crónica de Castela, pero introduce nela interpolacións da Historia de Guillerme de Tiro, seguramente a través dunha versión romance dalgún modo vinculada á Gran Conquista de Ultramar (Pérez Pascual ed. 1990: 123-31, 1991b: 389-92); e

4) achegas independentes, propias do compilador, bastante torpe no relativo á conciliación das súas fontes. Estas achegas, que buscan actualizar o discurso histórico a partir dos datos proporcionados polas crónicas galegas incorporadas no texto, introducen elementos que completan o resumo final da crónica galega segundo A2 cont, que falaba, nun pequeno apéndice, dos reis de Castela ata Sancho IV e Fernando IV; o cronista de 1404, que conserva íntegro este resumo (Lorenzo 2000: 388) engade referencias, de fontes descoñecidas, dos reinados dos diferentes monarcas casteláns dende Fernando IV a Henrique III ata o ano 1404 (Catalán 1992: 193, 1997: 236), en que pecha a narración, segundo as súas propias indicacións (Lorenzo 1993a: 185), nun esforzo de natureza semellante ao que se levou a cabo para rematar A2 ca. 1312.

En case todos os casos, as referencias desta parte final son breves, con excepción dalgún episodio relativo a Fernando IV, e dos episodios do reinado de Afonso XI entre a perda de Xibraltar (1333) e a batalla de Salado (1340); entre estes eventos, faise referencia á morte do fillo do conquistador mouro de Xibraltar durante una incursión ata Sevilla, nun texto moi próximo ao narrado na Crónica de Alfonso XI de Fernán Sánchez de Valladolid, que dataría de 1344 (Catalán 1997: 237). Pero hai un aspecto da Crónica de 1404 que non aparece referido noutras fontes, e son dous discursos que pronuncian o bispo de Mondoñedo e un cabaleiro chamado Johan García de Ferreira, que mata ao fillo do rei mouro. En concreto, a intervención de don Alvaro de Biedma, bispo de Mondoñedo, cun discurso sobre o pendón da igrexa de Mondoñedo, vitorioso entre o exército mouro ep isodio totalmente ficticio,- fai pensar que o autor da Crónica de 1404 era desta localidade, ou 
que o feito narrado estaba referido nalgunha historia mindoniense consultada polo autor (Catalán 1997: 239). Esta coincidencia relacionaría a Crónica de 1404 cunha cuestión que xa mencionamos: a posible procedencia mindoniense dos manuscritos galegos *Ax e A', relacionados coa Estoria de Espa$\tilde{n} a$, que reproducían in extenso unha referencia marxinal sobre a cidade contida en A1, constitutivo, á súa vez, de A, manuscrito, polo demais, propiedade da diocese de Mondoñedo na Idade Media (Fernández Ordóñez 2000: 239). Esta circunstancia establecería claramente unha estreita relación de dependencia global entre todos estes testemuños (Catalán 1997: 240) e fai deste centro de Mondoñedo o punto máis importante en Galicia da reprodución do discurso historiográfico en lingua vulgar.

No que se refire á tradución galega da General Estoria, integrada absolutamente no proxecto historiográfico universalista afonsí, a complexidade do proceso é semellante á que presenta no ámbito castelán. Este segundo proxecto de Afonso X o Sabio ten, en principio, unha dimensión máis ambiciosa que a primeira parte, a da Estoria de España, pero sen os seus problemas de copia e difusión; comezaríase arredor de 1270, de xeito semellante á outra gran compilación cronística, pero quedou incompleta en 1284, ano da morte do monarca; como consecuencia, chega só ao inicio da sexta parte, relativa a cuestións relacionadas coa Historia Sagrada. Hai indicios de que, de feito, ambos proxectos compartiron fontes (Fernández Ordóñez 1992: 159-202), pero a Estoria de España foi abandonada, chegado un certo momento, en beneficio desta nova compilación de carácter universal. Na súa composición utilizáronse fontes bíblicas e dos seus eséxetas, combinadas con elementos doutros tipos (Lorenzo 2000: 380), e cunha distribución dos tempos en función dos pobos eu dos reis- que protagonizaron as diferentes etapas da historia (Fernández Ordóñez 1992: 27-28). En parte a causa das dificultades na redacción da obra, existe un número de testemuños manuscritos moi desigual das diferentes seccións, reducíndose drasticamente o número de testemuños a partir da terceira parte. Como moitos outros manuscritos, o texto galego é de carácter fragmentario, porque só reproduce ata a metade do sétimo libro do Xénese (Lorenzo 2000: 381), dos dez que ten o Génesis orixinal castelán, que constitúe, á súa vez, o texto inicial da primeira parte das seis que ten a General Estoria afonsí (Gómez Redondo 1998: 686-796), o que dá unha idea do escasísimo contido do texto galego en relación coa obra orixinal. O noso manuscrito (ms. O.I.i da Biblioteca do Escorial), data do primeiro terzo do século XIV, aínda que a súa orixe castelá exacta é descoñecida; probablemente foi composto por un tal Nuno Freire, mencionado no ms. (Lorenzo 2000: 380), que Mariño Paz (1998: 154) identifica cun membro da familia dos Andrade con vínculos coa casa de Trastámara. De todas formas, sabemos con certeza que, ao igual que a familia de ma- 
nuscritos galegos A da Estoria de España, tamén a copia galega foi quen de ter unha certa influencia na tradición manuscrita castelá desta primeira parte; agora ben, a influencia, neste caso, ten un alcance moito mais puntual, limitado ao manuscrito castelán Y-III-12 de El Escorial, do século XV, que reproduce, sen alteracións de importancia, o mesmo texto que o seu orixinal galego (García Solalinde ed. 1930: xxxii-xxxiii e 1x, Martínez López ed. 1963: xviii-xix, Fernández Ordóñez 2002: 46 e 51).

Por outra banda, o discurso xurídico (o que dedicaremos unha atención moito menor en razón da escaseza de textos e do seu carácter fragmentario) ten unha orixe semellante ao discurso historiográfico; é dicir, que as leis das que conservamos manuscritos teñen, todas elas, a súa orixe en Castela, e son traducións, na súa maior parte, de orixinais da época de Afonso X o Sabio. Os textos conservados son, entre outros, os seguintes: o Foro Real (finais do século XIII ou principios do XIV), fragmentos dalgunhas Partidas (en concreto da Primeira, Terceira, Cuarta, Quinta, Sexta e Sétima Partidas; cf. Lorenzo 2000: 397-98) as Flores de Dereito e o Ordenamento de Alcalá de 1348, aos que habería que sumar outros textos menos importantes de localización problemática nalgúns casos (Lorenzo 2000: 393-401; nestas páxinas do investigador galego poderanse ler os pormenores do contido legal dos diferentes documentos). Nalgúns deles atopamos certas particularidades de interese: a versión galega do Fuero Real, datada entre finais do século xIII ou principios do XIV, está escrita en galego-leonés (Lorenzo 2000: 396), igual que outros textos xurídicos, como as versións que se conservan da Primeira Partida e das Flores de Dereito. A redacción dos textos nesta lingua mixta responde, en primeiro lugar, á vontade de establecer un criterio unificador de todas as particularidades lingüísticas de todo o territorio noroeste da Península (Mariño 1998: 174, a propósito das traducións do Fuero Real e as Flores de Dereito) pero, neste caso particular, únese a circunstancia da necesidade da difusión en todo o reino de Castela duns mesmos textos que organizaban o entramado xurídico polo que se rexían todos os súbditos do reino (Lorenzo 2000: 397). Isto xustifica, naturalmente, as demais traducións ao galego e, ata certo punto, a inexistencia dun código xurídico propio en Galicia (tamén un baleiro na literatura xurídica propia xustificaría a tradución en portugués, como comenta Ferreira 1993: 511 a propósito das Partidas) ${ }^{5}$. Por último, a existencia mesma destas traducións ao portugués dalgúns destes documentos, como as Flores de Dereito, moitas das Partidas (o texto de maior difusión)

5. "D. Dinis sentia uma enorme admiração pela obra literária, científica e legislativa do seu avô Daí, nada mais natural que empreendesse a tarefa de mandar traduzir obras do castelhano (...) embora a verdadeira razão devesse ser a não existencia de um autêntico corpo legal disponível para a aplicación do dereito". 
ou o Fuero Real, demostra que todo o Occidente peninsular, por razóns de diversa índole, asumiu os discursos xurídico e historiográfico procedentes de Castela, que se erixe en produtor e difusor dos mesmos a través da circulación e tradución de manuscritos.

\section{A DIMENSIÓN GALEGA}

Unha última fase da produción prosística, que, en termos xerais, se desenvolve moi tardiamente, ten unha dimensión unicamente galega, na súa produción e/ou no seu alcance. O texto dos Milagres de Santiago é o primeiro desta serie de obras de circulación limitada á nosa terra e de fontes puntuais tamén relacionadas con Galicia, aínda que, nalgúns casos, ditas fontes sexan obras de alcance universal. O Codex Calixtinus, compilación de textos xacobeos moi vinculada a Galicia, alomenos no seu contido, foi a base deste documento no que, ademais de incluírse extensas pasaxes do texto compostelanista, son integrados outros, procedentes de relatos menores, e algúns deles sen vínculos de ningún tipo coa cuestión xacobea. De tal xeito que os relatos que hoxe lemos no manuscrito son: milagres de Santiago o Maior e Santiago Alfeo, Vida e Paixón de Santiago Alfeo, Destrución de Xerusalén, Historia de Pilatos, Translación da cabeza de Santiago Alfeo, Pseudo Turpin, Guía de peregrinos, Epifanía e Asunción, reproducidos todos eles nunhas condicións moi particulares que de seguido veremos. Esta é a principal orixinalidade do texto galego, porque a tradución a linguas vernáculas do Codex Calixtinus é un feito que conta con moitos testemuños, non só en Europa, senón tamén, máis concretamente, na Península Ibérica (Fidalgo / Brea 2004). Lémbrese, por outra banda, que a data do texto conservado (finais do século xIV ou principios do xv) é, ata certo punto, enganosa, na medida en que o data avanzada do manuscrito non proba o atraso da tradución vernácula galega, senón unicamente o carácter tardío da copia conservada, o ms. 7455 da BN de Madrid; dado ademais que, con total seguridade, este manuscrito procede dunha copia anterior (Lorenzo 2000: 416), —o que se deduce, entre outros feitos, da incrible desorde interna, froito en parte da mala reorganización do contido da fonte- podemos afirmar que a adaptación do texto calixtino á lingua vernácula galega seguiu, probablemente, un proceso cronolóxico que non foi en exceso diferente doutras copias do mesmo texto noutras partes de Europa ou da Península Ibérica. Si pode que fose distinta, en cambio, a finalidade da compilación, quizais elaborada unicamente para a súa utilización no contorno de Santiago de Compostela.

Por outra banda, a xulgar pola heteroxeneidade de textos integrados no manuscrito (ademais do propio texto calixtino, cuxa estrutura, dun modo ou 
outro, tivo que ser claramente a base do conxunto), e a diversidade e dispersión das fontes (das que Pensado, ed. 1958: xxxi-clx, ofrece unha pormenorizada análise), esta compilación, deixando á parte a función dos relatos da Epifanía e a Asunción, estaría concibida, en gran medida, como un texto no que se construían dous relatos paralelos arredor dos dous Santiagos, Santiago o Maior e Santiago Alfeo, equiparación, por outra banda, non infrecuente.

Así, os milagres teñen unha natureza dobre: dunha banda, os catro primeiros, que son "anómalos" na medida en que non pertencen ao libro de milagres calixtino tradicional, pero que tampouco son atribuíbles con certeza a Santiago Alfeo, agás, quizais, o primeiro deles (Gómez Clemente ed. 2001: 28); doutra banda, o grupo de 22 milagres calixtinos, reproducidos a partir do texto do Liber Sancti Iacobi, pero copiados en parte de xeito fragmentario, en desorde, integrados nunha posición máis avanzada dentro do propio texto, e en parte intercalados co relato da Asunción, do que falaremos despois; é dicir, non hai unha copia coherente da serie de milagres, nin unha fonte única dos mesmos, aínda que a disposición dos textos seguintes ofrece, probablemente, a razón de semellante esquema organizativo.

En efecto, os textos que se len a continuación dos primeiros catro milagres, e inseridos despois dunha estraña referencia á Paixón de Santiago Zebedeo (ausente do manuscrito) e ao Pseudo Turpín (narración que se le máis adiante $)^{6}$ refírense, en maior ou menor medida, ao menor dos Santiagos, segundo sostén con gran lóxica, Gómez Clemente (ed. 2001: 30-31). A orde é a seguinte: paixón de Santiago Alfeo, destrución de Xerusalén, vida e morte de Pilatos, e translación da cabeza de Santiago Alfeo a Compostela (Pensado ed. 1958: 31-67). Todos estes textos parecen moi relacionados entre si, incluso na historia literaria e, de feito, gardan no texto unha gran coherencia interna (Pensado ed. 1958: xix-xxii). Evidentemente, algún deles ten un estraño encaixe nesta dinámica, como a presenza da historia de Pilatos, pero todos constitúen elementos indispensábeis na estoria citada no manuscrito que, segundo Gómez Clemente (ed. 2001: 30-31), sería a propia traxectoria da vida e paixón de Santiago Alfeo, de protagonismo, como vemos, crecente.

Neste punto engádense no manuscrito as versións do Pseudo Turpín e da Guía de peregrinos p- olo tanto, despois dos elementos máis innovado-

6. "Ata aquí vos cõtamos da paixõ et trasladaçõ de Santiago Zebedeu et das batallas que fezo Calrros en España, et ora vos cõtaremos de Santiago Alffeu" (Pensado ed. 1958: 19). Isto demostra a copia dun orixinal que gardaba a mesma orde de textos que o Calixtinus a- lomenos nesta parte- e que foi alterado de forma moi descoidada. 
res, relativos ao segundo Santiago- que carecen tamén dalgunhas follas; dende un certo punto de vista, o máis importante sería o Pseudo-Turpín (tradución do relato homónimo latino que constitúe o libro IV do Codexonde se narra a liberación do Camiño de Santiago polo emperador Carlomagno), conservado case completo no texto; pero a súa importancia como relato épico ten que matizarse un tanto, porque esta crónica, en realidade, só atopa o seu sentido no seo desta compilación miraculística, non como texto épico propiamente dito (algo que non sucedía necesariamente no orixinal latino, conservado en moitos manuscritos independentes, e de autoría difícil de establecer. Vid. López Martínez-Morás 2002). Sen embargo, si que podemos supoñer que o texto galego se inscribía nun contexto máis global de difusión de textos épicos en Galicia p- osiblemente a través de vías orais- dos que non se atoparon textos conservados. Naturalmente, como moitos dos demais textos do manuscrito, tamén o Pseudo Turpín presenta certas lagoas.

No que se refire á Guía, só podemos ler unha parte do capítulo 9 e o 11 completo, o que non permite saber ata onde chegou o esforzo real de tradución (Lorenzo 2000: 423-24); de feito, o epígrafe do texto (Pensado ed: 1958 : 151) remite exclusivamente a descricións propias de Compostela segundo o libro V do Codex, de enorme interese para o público vinculado directamente á cidade, o que pode suxerir que só foi traducida esta parte, pero non sabemos se esta selección tamén se produciu no orixinal.

Por fin, no texto do manuscrito aparecen, despois do texto da Guía e do primeiro grupo de milagres propiamente calixtinos, a Epifanía e a Asunción, textos de orientación relixiosa que non forman parte de compilación calixtina ningunha (Pensado ed. 1958: cxvii), integrados a partir de fontes independentes, e que son incorporados sen moitos elementos que sirvan de introdución, o que, en parte, está determinado polo estado fragmentario do manuscrito; no segundo caso, o relato da Asunción, como xa dixemos, está ademais interrompido por un grupo de milagres calixtinos. Unha vez rematados no folio 60v, estes milagres deixan paso á última parte da Asunción (Lorenzo 2000: 418).

A incomprensible presenza destes textos da Epifanía e a Asunción nunha compilación de relatos sobre os dous Santiagos, e a alteración que supoñen na unidade dos milagres calixtinos, fan imposible atopar unha lóxica coherente na organización deste manuscrito, onde non se pode establecer con certeza o grao de responsabilidade do tradutor e o do copista na súa elaboración; de feito, nin sequera é posible afirmar que estes últimos textos figurasen no orixinal copiado nos séculos XIV-XV. É posible determinar, a pesar de todo, que, á hora da formación da compilación, prevalecese a vontade de construír un texto que vencellase a ambos os Santiagos, pero o Calixtino tivo 
que ser, dalgún xeito, a base fundamental de todos os relatos, o que é comprensible por tratarse da obra máis célebre; os textos da Epifanía e a Asunción, calquera que fose o momento da súa integración, só atoparían a súa razón de ser na necesidade de introducir diversos elementos haxiográficos e edificantes nun só manuscrito, como parece propoñer Pensado (ed. 1958: cxvii). Pero tamén é posible pensar, dende un punto de vista codicolóxico, que en datas tardías se tomase a decisión de unificar códices distintos sen vínculos reais entre eles (como afirma Gómez Clemente ed. 2001: 35, seguindo a López Aydillo ed. 1918: 213, que propón a integración destes relatos nun só manuscrito cara ao século XVIII), por razóns meramente utilitarias, o que equivale a admitir que o caos organizativo se prolongou moito mais alá da Idade Media e que a unidade temática do texto foi, por regra xeral, claramente desprezada.

Como se pode comprobar, os problemas ecdóticos deste texto son sumamente complexos, e teñen difícil solución; como consecuencia, os distintos editores adoptaron criterios dispares, sobre todo no relativo a posición dos milagres: así, a edición de López Aydillo (ed. 1918) reproduce unha orde nos textos moi próxima á estrutura primitiva do Codex Calixtinus: 1) Milagres do Libro II, seguidos dos milagres independentes do Calixtino, e que se atopan ao principio do manuscrito; 2) textos vinculados á Paixón de Santiago Alfeo; 3) Pseudo Turpín; 4) Texto conservado da Guía de Peregrinos; 5) Epifanía e Asunción. Pensado (ed. 1958), pola súa banda, conserva os dous grupos de milagres do manuscrito, pero presenta os calixtinos como un bloque, sen ter en conta as interpolacións do texto (tamén Gómez Clemente ed. 2001: 133-58), e reproduce despois os relatos da Epifanía e a Asunción, e, aínda que recoñece non ter criterios suficientes para establecer un modelo de estrutura, a disposición dos textos e a supresión do libro I suxiren, segundo el, unha ordenación do tipo Libellus, cun número de textos máis reducido que no Codex (Pensado ed. 1958: xxxii, Gómez Clemente ed. 2001: 9, Fidalgo / Brea 2004: 193), contra a hipótese de Aydillo, que segue claramente a estrutura do Codex, o que cambia por completo a estrutura e, en certa medida, o espírito e a finalidade do texto.

Tamén cunha perspectiva compostelanista, pero moito máis restrinxida no seu alcance, a Crónica de Santa María de Iria é un dos textos máis tardíos da literatura en galego da Idade Media, e aparece cando esta lingua case non era xa utilizada no ámbito literario, pero nun momento en que aínda non apareceran obras en castelán escritas en Galicia (Mariño 1998: 184). A obra presenta certos problemas na tradición manuscrita propiciados polas dúas versións existentes, recoñecidas pola práctica totalidade dos críticos. Así, como indica Ramón Lorenzo (2000: 391), habería unha versión representada polo códice do século xv do Arquivo da Catedral de Santiago, que 
leva o nome de Ruy Vazquez, quen remata o proceso de escritura en 1468. Esta versión inclúe elementos relativos a II guerra irmandiña (Monteagudo 1995: 365, Lorenzo 2000: 392, Souto ed. 2001: 33) $\theta$ - que converte o texto nunha valiosa fonte de información sobre estes feitos históricos- e da que provirían dúas copias: o ms. 1228 da BNM (s. XvI), e o manuscrito 1924 da Biblioteca Universitaria de Salamanca (s. XVII); ningún destes dous testemuños sería, polo tanto, medieval. A outra versión está conservada nun manuscrito do século xvir no Vaticano (Barb. Lat. 3578), destinado a Tamayo de Vargas, moi vinculado á cuestión do padroado de Santiago no século XVII (Márquez Villanueva 2004: 345); esta última circunstancia xustificaría, a ollos dunha parte da crítica (sobre todo Souto ed. 2001), a hipótese dunha creación tardía e independente deste último testemuño, que constituiría, por tanto, unha falsificación (Souto ed. 2001: 22 e n. 24). Segundo este punto de vista, o autor real do texto do século xv sería Ruy Vásquez, clerigo de Santa Vaya de Chaçin (Carro García ed. 1951: 94), o asinante do manuscrito de Compostela, aínda que Fernán Rodríguez de Leira, cóengo compostelán, sería, cando menos, o promotor da súa elaboración (Souto ed. 2001: 18, 26 e ss.).

Pero é posible soster tamén que a copia do século xvII destinada a Tamayo de Vargas é un herdeiro directo doutro manuscrito, hoxe desaparecido, do século xv, atribuído, coma aquel, a Juan Rodríguez del Padrón, que supostamente escribiría a obra ca. 1444 (Lorenzo 2000: 391, Monteagudo 1995: 361 e 376 n. 8 establece incluso denominacións distintas para ambas as dúas versións: a de 1444, perdida no seu manuscrito orixinario, recibiría a denominación de Historia Iriense e a de 1468, atribuída a Ruy Vazquez, sería a Crónica de Santa María de Iria; este investigador, como a maior parte da crítica, fai depender a segunda versión da primeira). Esta autoría atribuída a Rodríguez del Padrón, aparentemente inxustificada, e destinada fundamentalmente a dotar de prestixio á obra, é en parte tomada en consideración por Mackenzie (1988: 422), aínda que con moitas reservas.

A pesar das diverxencias da crítica sobre estas cuestións, parece claro que a influencia do texto, cun obxectivo claramente compostelanista, non pasou no seu tempo das fronteiras de Galicia, o que se manifesta, paradoxalmente, no feito de que é o único texto prosístico galego cuxo manuscrito máis importante non saíu do lugar no que foi elaborado e para o que foi creado.

Como tal documento compostelanista, o texto presenta a historia do bispado de Iria Flavia ata a transferencia da sé a Santiago, utilizando, profusa e fundamentalmente, o Cronicon Iriense (s. xI) e a Historia Compostelana (s. XII), redactada baixo influencia de Xelmírez. Esta integración prodúcese de xeito desigual, porque mentres o Cronicon é traducido e integrado sen especiais dificultades (Monteagudo 1995: 365), o recurso á Historia Compostela- 
na interrómpese na narración dos feitos do ano 1108; nese momento decae na Historia o protagonismo de arcebispo, principal motivo de interese na adaptación desta crónica compostelá no texto de mediados do século xv (segundo afirma Souto ed: 2001: 141, aínda que parece ser que outras pasaxes da Historia foron integradas noutras partes do texto romance). A finalidade e o público do texto, destinado en principio a reforzar a autoridade de primeira sede de Iria (Carro García ed. 1951: 9, Lorenzo 2000: 391), parecen xustificar sobradamente a súa creación e difusión: a crónica estaba deliberadamente limitada a un público formado por individuos pertencentes á clase eclesiástica compostelá e polas "novas" autoridades laicas" (Souto ed: 2001: 34) no contexto dos convulsos sucesos de mediados do século xv, que, alomenos, xustifican a versión de 1468 e as reivindicacións de carácter económico que aparecen no documento.

\section{ConClusións}

O panorama presentado nas páxinas precedentes permiten amosar un claro desenvolvemento da prosa medieval galega no que poderíamos denominar fase 1 , definida fundamentalmente pola recepción e reprodución de textos producidos fora de Galicia. Esta tendencia, que se prolonga ata datas moi tardías, non se ve continuada por unha fase 2 , de creación de obras orixinais vernáculas a partir dos modelos foráneos, e isto principalmente pola influencia cada vez maior do modelo cultural castelán, que substituíu o galego como lingua de creación literaria. As evidencias determinan, porén, que foi o castelán o que lle proporcionou ao sistema literario galego, como produtor e transmisor, moitas das obras que serviron de modelo para as traducións que completan a devandita fase 1, como a Cronica troiana ou moitos dos textos historiográficos ou xurídicos.

Nestas condicións, parece claro que o galego non quedou reducido, nesta fase 1, a unha posición de marxinalidade; as noticias que temos permiten, máis ben, falar dunha certa implicación de importancia desta produción nun ámbito cultural progresivamente dominado polo castelán. Así, as versións galegas influíron decisivamente na configuración da tradición manuscrita de diferentes obras historiográficas; posiblemente están na orixe da versión da Polimétrica e da Historia Troyana de Afonso XI, que, á súa vez, é orixe dunha historia troiana en galego datada en 1373; un manuscrito de Salamanca, que intercala o galego e o castelán, é un testemuño importante desta mesma tradición clásica na Península Ibérica; a versión galega do Tristan en prose é importantísima como proba da circulación na Península da versión VII do roman francés; quizais un antecedente galego está na base do ma- 
nuscrito 9611 da BN de Madrid, que reproduce o roman central da Vulgata; todas estas cuestións fannos concluír que a fase 1 da literatura galega en prosa nunca se mantivo como un sistema pechado; a prosa galega funcionou máis ben como a produción lírica, que en ningún momento quedou limitada a unha cuestión interna, nin na época dos grandes trobadores nin na chamada escola da "decadencia" galego-castelá.

Porén, a presión do modelo cultural castelán, e a riqueza da súa produción nos xéneros non líricos, levou á adopción desta última lingua como elemento vehicular da produción prosística posterior, o que, en certa forma, é a consecuencia natural da implicación da produción galega de fase 1 no sistema literario en castelán, con máis posibilidades de difusión e máis prestixio (como demostra a súa implantación, a partir dun certo momento, tamén en Portugal seg undo vemos na historiografía deste tempo e nalgúns casos posteriores, como o de Gil Vicente- - Navarra e Aragón). Este prestixio é, a fin de contas, a razón pola que algún manuscrito da Crónica de Iria atribúe a autoría da obra a Juan Rodríguez del Padrón, autor galego célebre neste século pola súa produción na lingua de Castela.

É curioso observar, ademais, que os textos cunha maior problemática dende o punto de vista da composición, da estrutura e da tradición manuscrita, son, por regra xeral, aqueles que foron concibidos para un ámbito de recepción pechado: os Milagres de Santiago e a Crónica de Santa María de Iria, o segundo dos cales foi incluso destinado a un público pertencente a un entorno clerical sen preocupacións de carácter especificamente literario.

De todas formas, a situación suxerida polos textos conservados hoxe ten certamente un valor relativo, porque, como é sabido e nós xa apuntamos neste mesmo traballo, unha gran parte dos textos en galego foi destruída por razóns de distinta natureza, entre as cales non se pode excluír a falta de interese pola cultura e pola propia produción, como xa apunta, entre outros, Ramón Lorenzo (2000: 367; este fenómeno, con todo, non é exclusivo da literatura galega: cf. Deyermond 1995: 20-28). Esta desaparición xeneralizada de manuscritos explica parcialmente a posición actual da crítica, porque o escaso número de textos conservados fai que se lle conceda unha importancia desmedida a textos como o Libro de Albeitaria, que, en condicións normais, sería claramente considerado marxinal dentro da produción galega. Estas causas, polo tanto, obrigan tamén a pensar que o labor de tradución foi necesariamente maior e máis importante do que sabemos hoxe, como podería suxerir, indirectamente, a produción documental en galego destes séculos, a máis numerosa de España despois da de Cataluña (Monteagudo 1999: 125). De feito, as continuas referencias nas obras conservadas a outras das que non temos versións en galego amosan, alomenos, a evidencia da circulación regular de manuscritos en galego ou en castelán coñecidos (e enten- 
didos) por un público galego. Esta situación, por último, suxire tamén que, aínda que a literatura galega en prosa non foi tan forte como para desenvolver xéneros propios, non é imposible supoñer que se escribiran algunhas obras orixinais a partir dos modelos que xa coñecemos, como algún roman autóctono ou algunha crónica señorial ou biográfica, esperable nun escenario cultural non totalmente empobrecido onde o mecenado da nobreza é responsable absoluta dos textos da fase 1 . Aínda que isto permanece, como é natural, no estado de mera hipótese. 